\title{
Penerapan Metode AHP dan SAW Dalam Kelayakan Pemberian Kredit Motor
}

\author{
Sarwindah ${ }^{1, *}$, Marini' ${ }^{2}$, Syarah $^{3}$ \\ ${ }^{1}$ Program Studi Bisnis Digital, ISB Atma Luhur, Pangkalpinang, Indonesia \\ ${ }^{2}$ Program Studi Sistem Informasi, ISB Atma Luhur, Pangkalpinang, Indonesia \\ ${ }^{3}$ Program Studi Teknik Informatika, STMIK Dharma Putra, Jakarta, Indonesia \\ Email: 1,*indah_syifa@atmaluhur.ac.id, 2arinimarini44@atmaluhur.ac.id, ${ }^{3}$ sarah.setiaji20@gmail.com \\ Email Penulis Korespondensi: indah_syifa@atmaluhur.ac.id
}

\begin{abstract}
Abstrak-Dalam penelitian ini membandingan dua metode dalam pengambilan keputusan kelayakan pemberian kredit motor yaitu Analitical Hierarchy Process (AHP) dan metode Simple Additive Weighting (SAW) untuk mengetahui bobot nilai akurasi dalam kelayakan pemberian kredit motor. Hasil berdasarkan Matrik Faktor Pembobotan Hirarki dengan AHP Untuk Semua Kritera yang dinormalkan pembobotan hirarki untuk semua kriteria dengan unsur-unsur pada tiap kolom dibagi dengan jumlah total pada kolom yang bersangkutan, maka akan diperoleh bobot relatif yang dinormalkan. Nilai vektor eigen dihasilkan dari rata-rata nilai bobot relatif untuk tiap baris menunjukan bahwa kriteria yang paling penting bagi nasabah yang ingin mengajukan pengajuan kredit. Penghasilan dengan bobot 0,649 atau 64,9 \%, kemudian disusul Kartu keluarga deng an nilai bobot 0,088 atau $8,8 \%$, dan Domisili adalah 0,21 atau $21 \%$. Sedangkan Hasil berdasarkan perengkingan menggunakan metode SAW Untuk Semua Kritera yang dinormalkan pembobotannya adalah didapatkan hasil perankingn $V_{1}$ merupakan peringkat pertama karena memiliki nilai yang lebih besar dari nilai yang lain sebesar 1.03 dimana $\mathrm{V}_{1}$ merupakan nilai preferensi dari alternatif $A_{1}$, sehingga $A_{1}$ dalam kasus ini Yogi Danuarta yang menjadi alternatif terbaik atau Calon nasabah yang terpilih untuk mendapatkan kredit motor.
\end{abstract}

Kata Kunci: Penunjang Keputusan; Pemberian Kredit; AHP dan SAW

Abstract-In this study, two methods were used to determine the feasibility of giving motorbike credit, namely the Analytical Hierarchy Process (AHP) and the Simple Additive Weighting (SAW) method to determine the weight of the accuracy value in the feasibility of granting motor loans. Results based on the Hierarchical Weighted Factor Matrix with AHP for all criteria normalized hierarchical weighting for all criteria with the elements in each column divided by the total number in the respective column, then you will get the normalized relative weight. The eigenvector value generated from the average relative weight value for each row shows that the most important criterion for customers who wish to apply for credit. Income with a weight of 0.649 or $64.9 \%$, then followed by a family card with a weight of 0.088 or $8.8 \%$, and domicile is 0.21 or $21 \%$. Whereas the results based on ranking using the SAW method for all Kritera whose weighting is normalized is that the V1 ranking is the first rank because it has a value greater than the other values of 1.03 where V1 is the preference value of alternative A1, so that A1 in this case is Yogi Danuarta who be the best alternative or selected prospective customers to get motorbike loans.

Keywords: Decision Support; Credit Extension; AHP and SAW

\section{PENDAHULUAN}

Perusahaan memegang teguh dan selalu berkomitmen untuk memberikan pelayanan terbaik terhadap konsumen dan mitra bisnis, melalui pelayanan optimal yang didukung oleh pengelolaan sumber daya manusia yang terarah, terpadu dan berkesinambungan, serta ketersediaan infrastruktur yang memadai.PT. Mandala Multifinance adalah adalah perusahaan yang bergerak pada leasing, Perusahaan yang memfokuskan diri pada kegiatan usaha pembiayaan konsumen, khususnya pembiayaan kendaraan roda dua. Banyaknya pemohon kredit yang mengajukan kredit dengan kondisi ekonomi yang berbeda-beda menuntut kejelian Credit Analyst dalam pengambilan keputusan. Pada sistem yang berjalan saat ini Kriteria yang dijadikan acuan dalam pengambilan keputusan pemberian kelayakan kredit kepada konsumen kredit oleh bagian Credit Analyst, Yaitu kepribadian pemohon kredit, kemampuan membayar pemohon kredit (slip gaji), Jumlah tanggungan (kartu keluarga), uang muka pemohon kredit dan jaminan pemohon.Sistem yang berjalan saat ini belum berjalan dengan baik karena masih terdapatnya beberapa konsumen yang memiliki kredit macet seperti pembayaran kredit yang terlambat maupun pembayaran kredit yang tidak di bayarkan oleh konsumen sehingga menyebabkan berkurangnya profit perusahaan leasing. Perhitungan penilaian kriteria pemohon kredit dengan menentukan perubahan acuan kriteria yaitu penghasilan (slip gaji), Jumlah Tanggungan (Kartu keluarga), Domisi (KTP). Dalam penelitian ini sistem dibuat menggunakan bahasa pemograman PHP dan database Mysql dengan metode pengembangan perangkat lunak System Development Life Cycle (SDLC) yang memiliki tahapan pengembangan yaitu Tahapan Analisa Kebutuhan Sistem, Tahapan Perancangan Sistem, Tahapan Desain Sistem, dan Tahapan Implementasi Sistem. Manfaat dari penelitian ini adalah untuk membantu Credit Analystdalam kegiatan pengambilan keputusan konsumen layak kredit. Tujuan yang ingin dicapai pada peneltian ini adalah untuk membuat sistem pendukung keputusan pemberian kelayakan kredit kepada konsumen dengan menerapkan kriteria penilaian kelayakan kredit yaitu penghasilan (slip gaji), jumlah tanggungan (kartu keluarga), domisi (KTP) disertai bobot penilaian pada setiap kriteria. 
Penelitian penelitian terdahulu terkait sistem pendukung keputusan sudah banyak di lakukan oleh kalangan peneliti, seperti yang dilakukan oleh Wardani (2010) dengan judul Aplikasi Pemberian Bantuan Modal Usaha Pertanian Menggunakan Metode AHP dan Model Simple Additive Weighting (SAW). Metode AHP model SAW digunakan untuk mencari penjumlahan terbobot dari rating kepentingan pada setiap alternatif pada semua kriterianya. Hasil akhir dari penelitian tersebut berupa SPK dalam pemberian pinjaman modal usaha yang dapat membantu melakukan pemilihan dalam menyalurkan bantuan pinjaman usaha pertanian sehingga bantuan pinjaman menjadi tepat sasaran. Dengan menggunakan metode AHP model SAW, SPK tersebut memiliki keakurasian nilai sebesar $82 \%$ dalam menentukan prioritas penerima pinjaman modal usaha berdasarkan kriteria yang digunakan [1].

Kemudian penelitian yang dilakukan oleh Oktapura dan Noersasongko (2009) dengan judul SPK Kelayakan Pemberian Kredit Motor Menggunakan Metode SAW Pada Perusahaan Leasing HD Finance menghasilkan SPK yang dapat memberikan rekomendasi dan pertimbangan dalam pengambilan keputusan realisasi kredit berdasarkan kriteria yang telah ditentukan [2]. penelitian yang dilakukan oleh Sarwindah dan marini (2020) dengan judul Penunjang Keputusan Dalam Kelayakan Pemberian Kredit Motor Pada PT.Mandala Multifinance dengan tujuan untuk membantu Credit Analyst dalam kegiatan pengambilan keputusan konsumen layak kredit. Tujuan yang ingin dicapai pada peneltian ini adalah untuk membuat sistem pendukung keputusan pemberian kelayakan kredit kepada konsumen dengan menerapkan kriteria penilaian kelayakan kredit yaitu penghasilan (slip gaji), jumlah tanggungan (kartu keluarga), domisi (KTP) disertai bobot penilaian pada setiap kriteria [3].

Pada penelitian yang dilakukan oleh Amardyah Amborowati (2004). Sistem Penunjang Keputusan Pemilihan Perumahan dengan Metode AHP menggunakan Expert Choice.sistem Penunjang Keputusan Pemilihan dengan skoring melalui kuesioner dan diolah menggunakan metode AHP dengan Process Analytical methods using a software expert choicebahwa kebutuhan akan perumahan KPR sangat penting bagi calon konsumen.[4], pada penelitian sebelumnya penelitian Sarwindah (2018). Sistem Penunjang Keputusan Pemilihan Perumahan Subsidi BerdasarkanKebutuhanKonsumen dengan metodeAHP.KNSI2018, pp. 668-673.Dengan mengacu kepada solusi Analytical Hierarki Process (AHP) dalam membantu membuat keputusan, seorang decision maker dapat mengambil keputusan tentang perumahan yang sesuai dengan yang dinginkan secara cepat dengan membandingkan semua kriteria yang ada . Berdasarkan hasil analisis dan kuisioner yang telah di edarkan pada responden didapatlah kriteria tertinggi adalah kualitas bangunannya yang kokoh menjadi prioritas utama konsumen [5].

Pada penelitian Erikson S.Sinaga, Strategi Process Migrasi Proprietary Software Ke Open Source Software di Perusahaan Dengan Pendekatan Analytical Hierarchy Process (AHP), Studi Kasus: SGU, Tangerang, 2008.Teknik analisa dalam menentukan bobot prioritas langkah yang hendak dilakukan menggunakan pendekatan Analytical Hierarchy Process (AHP). Sebagai ruang lingkup penulisan tesis, dilakukan penelitian di Swiss German University, Tangerang, yang saat ini sedang melakukan proses migrasi pemanfaatan software dari proprietary ke open source software [6], pada penelitian Sarwindah, 2013. Kajian Pemilihan Software Desain Grafis Untuk Pembelajaran Dengan Metode AHP Pada SMK Muhamadiyah 9. SEMNASTEKNOMEDIA. 2013Permasalahan pemilihan software desain grafis di SMK Muhammadiyah 9 merupakan objek penelitian,yang menghasilkan jawaban yang di inginkan yaitu software Adobe Photoshop yang menjadi prioritas dan dapat di implementasikan untuk pembelajaran di sekolahan SMK Muhammadiyah 9 [7].

Tanto (2014) melakukan penelitian dengan judul Perancangan Sistem Pendukung Keputusan Pemberian Kredit Pemilikan Rumah (Kpr) Dengan Metode Simple Additive Weighting. Penerapan metode SAW dalam pemberian KPR memiliki beberapa kriteria yang menjadi dasar pengambilan keputusan antara lain character, capacity, capital, collateral dan condition. Hasil penelitian ini adalah membuat aplikasi sistem pendukung keputusan pemberian KPR untuk memberikan kemudahan dalam pengambilan keputusan pemberian KPR. [8], pada penelitian Adianto, Tomy Reza, dkk. 2017. Sistem Pendukung Keputusan (SPK) Pemilihan Rumah Tinggal di Perumahan Menggunakan Metode Simple Additive Weighting (SAW) (STUDI KASUS : KOTA SAMARINDA). Prosiding Seminar Ilmu Komputer dan Teknologi Informasi, Vol. 2, No. 1, hlm. 197-201. Metode Simple Additive Weighting (SAW) merupakan salah satu metode untuk penyelesaian masalah multiattribute decision making. Konsep dasar metode SAW adalah mencari penjumlahan terbobot dengan rating kinerja pada setiap alternatif pada semua atribut [9].

Pada penelitian Butar-Butar, Oktovantua Tp. 2015. Sistem Pendukung Keputusan Rekomendasi Penerima Bantuan Siswa Miskin (BSM) Dengan Metode Simple AdditiveWeighting (SAW) (Studi Kasus : SMP N2 Tarabintang).Pelita Informatika Budi Darma, Volume : IX, Nomor: 3, hlm. 162-165.Hasil akhirdari penelitian ini didapatkan bahwa sistem pendukung keputusan dengan metode SAW mampu mengatasipermasalahan dalam menyeleksi calon penerima bantuan siswa miskin (BSM)[10]. Pada penelitian Bunafit, N., 2013, Dasar Pemrograman Web PHP - MySQL Dengan Dreamweaver, GavaMedia[11] dan Pada penelitian yang dilakukan oleh Amardyah Amborowati (2004). Sistem Penunjang Keputusan Pemilihan Perumahan dengan Metode AHP menggunakan ExpertChoice.sistem Penunjang Keputusan Pemilihan dengan skoring melalui kuesioner dan diolah menggunakan metode AHP dengan Process Analytical methods using a software expert choicebahwa kebutuhan akan perumahan KPR sangat penting bagi calon konsumen [12]. kemudian penelitian yang dilakukanSotir, Sotirov and Andrey, Nenov .Tutorials Expert Choice, Vol.4 No.1, Maret 2006, ISSN:1693 - 
5373, Computer Science Journal [13], dan pada penelitian sebelumnya penelitianSarwindah (2018). Sistem Penunjang Keputusan Pemilihan Perumahan Subsidi BerdasarkanKebutuhanKonsumen dengan metodeAHP.KNSI2018, pp. 668-673.Dengan mengacu kepada solusi Analytical Hierarki Process ( AHP ) dalam membantu membuat keputusan, seorang decision maker dapat mengambil keputusan tentang perumahan yang sesuai dengan yang dinginkan secara cepat dengan membandingkan semua kriteria yang ada . Berdasarkan hasil analisis dan kuisioner yang telah di edarkan pada responden didapatlah kriteria tertinggi adalah kualitas bangunannya yang kokoh menjadi prioritas utama konsumen [14].

Pada penelitian Haerani, Ellin dan Ramdaril. 2017. Sistem Pendukung Keputusan Pendistribusian Zakat pada BAZNAS Kota Pekanbaru Menggunakan Fuzzy Multiple Attribute Decission Making (FMADM) dan Simple Additive Weighting (SAW). Jurnal Ilmiah Teknik Informatika. Vol.10 No.2,hlm. 159-168. Pada sistem ini akan melakukan pengolahan terhadap data masukan yang diberikan sehingga menghasilkan keluaran data berupa mustahik yang memiliki nilai $\mathrm{V}$ tertinggi yang otomatis menjadi mustahik yang direkomendasikan untuk mendapatkan zakat sesuai dengan program kerja yang ada [15]. dan pada penelitian Lipursari, Anastasia. 2013. Peran Informasi Manajemen (SIM) DalamPengambilan Keputusan. Jurnal STIE SEMARANG, Vol. 5, No. 1, hlm 26-37.Metode pengolahan data adalah suatu proses menerima data sebagai masukan, memproses menggunakan program tertentu, dan mengeluarkan hasil proses data tersebut dalam bentuk informasi [16].

Berdasarkan penelitian terdahulu maka penulis berinisiatif bertujuan untuk menerapkan metode AHP dalam menghasilkan bobot dan menggunakan metode SAW dalam menentukan perangkingan dalam kelayakan pemberian kredit motor pada PT.Mandala Multifinance. Hasil dari penelitian diharapkan dapat memberikan keputusan yang tepat dalam kelayakan pemberian kredit motor.

\section{METODOLOGI PENELITIAN}

Dalam penelitian ini metode Analitycal Hierarcy Process(AHP) digunakan untuk menentukan bobot dari kriteria kriteria yang telah ditetapkan di PT. Mandala Multifinance. Kriteria kriteria yang digunakan adalah Penghasilan, Kartu Keluarga dan Domisili.

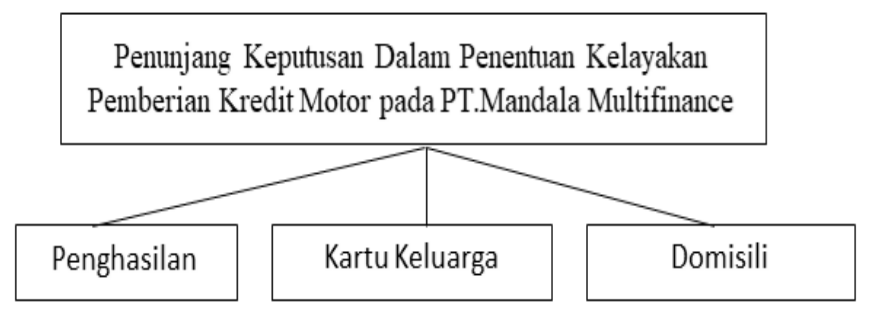

Gambar 1. Kriteria dalam penetapan penentuan kelayakan pemberian kredit motor

Dalam penentuan bobot menggunakan metode memiliki langkah-langkah, sebagai berikut:

1. Membuat matrik perbandingan berpasangan dari setiap kriteria yang ditentukan

$$
\mathrm{W}=\left[W_{i} / W_{j}\right]=\left[\begin{array}{lll}
W_{1} / W_{1} & \cdots & W_{1} / W_{n} \\
W_{2} / W_{1} & \cdots & W_{2} / W_{n} \\
W_{n} / W_{1} & \cdots & W_{n} / W_{n}
\end{array}\right]
$$

2. Menentukan prioritas elemen

a. Membuat perbandingan pasangan dengan cara membandingkan elemen secara berpasangan sesuai kriteria yang diberikan

b. Setiap matriks perbandingan berpasangan diisi dengan menggunakan bilangan untuk mendeskripsikan tingkat prioritas relatif antar elemen

$$
\mathrm{A}=\left[a_{i j}\right]=\left[\begin{array}{ccc}
1 & \cdots & a_{1 n} \\
1 / a_{1} & \cdots & a_{2 n} \\
1 / a_{1 n} & \cdots & 1
\end{array}\right]
$$

3. Sintesis merupakan perpaduan tentang pertimbangan-pertimbangan terhadap perbandingan berpsangan untuk memperoleh prioritas yang terurut dengan cara :

a. Jumlahkan setiap kolom pada matriks

b. Bagikan semua nilai dari setiap kolom dengan jumlah kolom matrik untuk mendapatkan normalisasi matriks

c. Jumlahkan semu nilai barsi kemudin bagikn dengn jumlah elemen untuk mendapatkan nilai rata- rata.

$$
a_{i j}^{*}=a_{i j} / \sum_{i j}^{n}=a_{i j}
$$

4. Mengukur Konsistensi yang artinya dalam membuat sebuah keputusan, penting untuk mengetahui sebeberapa baik konsistensi yang ada untuk menghindari adanya konsistensi yang rendah. Caranya adalah sebagai berikut : 


\section{JURNAL MEDIA INFORMATIKA BUDIDARMA}

Volume 5, Nomor 1, Januari 2021, Page 58-65

ISSN 2614-5278 (media cetak), ISSN 2548-8368 (media online)

Available Online at https://ejurnal.stmik-budidarma.ac.id/index.php/mib

DOI 10.30865/mib.v5i1.2466

a. Kalikan nilai setiap kolom pertama dengan prioritas relatif elemen pertama, nilai pada kolom dua dikalikan dengan prioritas relatif elemen kedua dan seterusnya.

b. Jumlahkan nilai setiap baris.

c. Nilai total penjumlahan nilai baris dibagi dengan nilai elemen prioritas relatif yang bersangkutan.

d. Cari nilai $\lambda$ Maks dengan cara menjumlahkan hasil bagi dengan banyaknya elemen yang ada. $W_{i}=\sum_{i=1}^{n} a_{i j}^{*} / n$

5. Menghitung Consistency Index dengan persamaan berikut.

$\mathrm{CI}=(\lambda$ maks $-\mathrm{n}) /(\mathrm{n}-1)$

6. Menghitung Rasio Consistency Ratio (CR) dengan persamaan berikut. $\mathrm{CR}=\mathrm{CI} / \mathrm{IR}$

7. Melakukan pemeriksaan terhadap konsistensi hierarki. Jika nilai lebih dari $10 \%$, maka penilaian data judgment harus diperbaiki. Akan tetapi, jika rasio konsistensi (CI/IR) kurang atau sama dengan 0,1 maka hasil prhitungan yang telah dilakukan dapat dinyatakan benar.

Dalam penetapan rangking pada penelitian ini metode Simple Additive Weighting (SAW). Perangkingan dalam perhitungan terakhir berdasarkan penghasilan, kartu keluarga dan domisili. Langkah-langkah metode dalam metode SAW adalah:

1. Menghitung matrik ternormalisasi

Untuk kriteria keuntungan

$$
r_{i j}=\frac{X_{i j}}{\max _{i} X_{i j}}
$$

Untuk kriteria biaya

$$
r_{i j}=\frac{\min _{i} X_{i j}}{X_{i j}}
$$

2. Menghitung preferensi untuk penetapan rangking

$$
\mathrm{v}_{\mathrm{i}}=\sum_{i=0}^{n} w_{j} \cdot r_{i j}
$$

\subsection{Tahapan Pengembangan Sistem}

Dan dalam penelitian ini menggunakan metode penelitian statistik deskriptif. Metode statistik deskriptif yaitu metode yang meneliti mengenai fakta-fakta, objek serta sifat dari permasalahan dan kebutuhan yang dikumpulkan kemudian dianalisis sehingga menghasilkan kesimpulan dari deskripsi secara sistematis, faktual dan akurat.Dalam perancangan perangkat lunak, penelitian ini menggunakan metode SDLC.

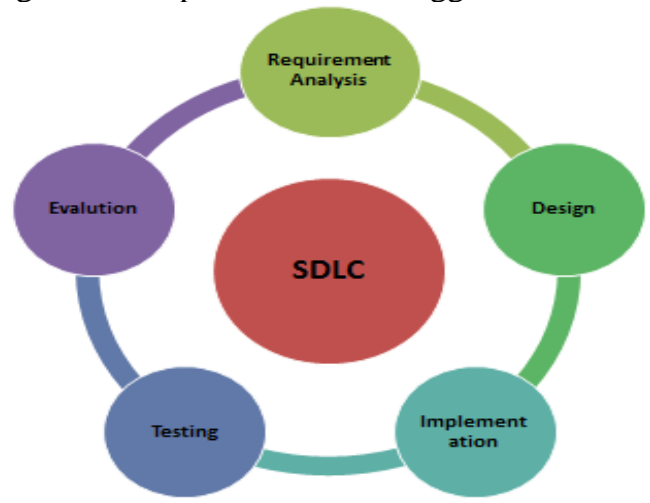

Gambar 2. Metode SDLC (System Development Life-Cycle)

Setelah merumuskan Kerangka konsep maka dilanjutkan ke Tahapan Pembangunan Sistem yakni:

1) Analisa Kebutuhan Sistem

Tahap menganalisis data yang telah dikumpulkan merupakan tahap analisis berkaitan dengan proses dan data yang dibutuhkan oleh sistem. Analisis harus mencakup kebutuhan pengguna, interface, dan fungsi yang dibutuhkan. Hasil analisa yaitu berupa model sistem yang telah terstruktur.

2) Perancangan Sistem

Berdasarkan kebutuhan sistem yang telah dianalisis maka sistem penunjang keputusan menggunakan metode Analytical Hierarchy Process (AHP) dan metode Simple Additive Weighting (SAW).

3) Implementasi Sistem Implementasi sistem pada tahap ini, peneliti berfokus pada penerapan metode Analytical Hierarchy Process (AHP) dan metode Simple Additive Weighting (SAW) untuk menentukan pemberian kredit kepada nasabah.

4) Pengujian dan Analisis 


\section{JURNAL MEDIA INFORMATIKA BUDIDARMA}

Volume 5, Nomor 1, Januari 2021, Page 58-65

ISSN 2614-5278 (media cetak), ISSN 2548-8368 (media online)

Available Online at https://ejurnal.stmik-budidarma.ac.id/index.php/mib

DOI 10.30865/mib.v5i1.2466

Pengujian dilakukan terhadap sistem yang telah dibangun. Pengujian ini bertujuan untuk membuktikan konsep dan sesuai kebutuhan pengguna. Pengujian kualitas dari perangkat lunak yang dibangun menggunakan pengujian Mc'Call

5) Penarikan Kesimpulan

Penarikan Kesimpulan dilakukan berdasarkan hasil analisa dan pengujian yang telah dilakukan, apakah hasil dari perancangan sistem dapat menjawab pertanyaan pada rumusan masalah dan sesuai dengan hipotesis serta kebutuhan pengguna.

\section{HASIL DAN PEMBAHASAN}

\subsection{Penerapan AHP Dalam Menentukan Bobot}

Pada langkah awal penulis menggunakan metode AHP dalam penentuan bobot terhadap sejumlah kriteria yang digunakan. Berikut langkah perhitungan bobot yang digunakan. Hasil analis prefensi gabungan dari 10 responden menunjukkan bahwa : kriteria penghasilan 4 kali lebih penting kriteria kartu keluarga dan 8 kali lebih penting dibanding dengan kriteria domisili. Sedangkan kartu keluarga 6 kali penting dibanding kriteria domisili. Maka matrik perbandingan hasil referensi diatas adalah :

Tabel 1. Matrik faktor pembobotan hirarki untuk semua kriteria

\begin{tabular}{lccc}
\hline Kriteria & Penghasilan & $\begin{array}{c}\text { Kartu } \\
\text { Keluarga }\end{array}$ & Domisili \\
\hline Penghasilan & 1 & 6 & 4 \\
Kartu Keluarga & $1 / 6$ & 1 & $1 / 3$ \\
Domisili & $1 / 4$ & 3 & 1 \\
\hline
\end{tabular}

Tabel 1 merupakan gambaran matrik faktor pembobotan hirarki untuk semua kriteria. Adapun kriteria yang menjadi acuan yaitu bakat, minat, kualitas jurusan dan peluang karir.

Tabel 2. Matriks faktor pembobotan hiraki untuk semua kriteria yang disederhanakan

\begin{tabular}{|c|c|c|c|}
\hline Kriteria & Penghasilan & $\begin{array}{c}\text { Kartu } \\
\text { Keluarga }\end{array}$ & Domisili \\
\hline Penghasilan & 1 & 6 & 4 \\
\hline Kartu Keluarga & 0.167 & 1 & 0.333333 \\
\hline Domisili & 0.250 & 3.000 & 1 \\
\hline$\sum$ & 1.4167 & 10.0000 & 5.3333 \\
\hline
\end{tabular}

Tabel 2 merupakan tabel pembobotan hirarki untuk semua kriteria yang telah disederhanakan dan kemudian menjumlahkan dari masing-masing kriteria.

Tabel 3. Matrik Faktor Pembobotan Hirarki Untuk Semua Kritera yang dinormalkan

\begin{tabular}{ccccc}
\hline Kriteria & Penghasilan & $\begin{array}{c}\text { Kartu } \\
\text { Keluarga }\end{array}$ & Domisili & $\begin{array}{c}\text { Vector } \\
\text { Eigen }\end{array}$ \\
\hline Penghasilan & 0.7059 & 0.6000 & 0.7500 & 0.685 \\
Kartu Keluarga & 0.1176 & 0.1000 & 0.0625 & 0.093 \\
Domisili & 0.1765 & 0.3000 & 0.1875 & 0.221 \\
\hline
\end{tabular}

Tabel 3 merupakan tabel pembobotan hirarki untuk semua kriteria dengan unsur-unsur pada tiap kolom dibagi dengan jumlah total pada kolom yang bersangkutan, maka akan diperoleh bobot relatif yang dinormalkan. Nilai vektor eigen dihasilkan dari rata-rata nilai bobot relatif untuk tiap baris.

$$
\begin{aligned}
(\lambda \text { maksimum }) & =(1.417 \times 0.685)+(10 \times 0.093)+(5.333 \times 0.21) \\
& =\mathbf{3 . 0 8 5 0 5}
\end{aligned}
$$

Selanjutnya mencari nilai eigen maksimum ( $\lambda$ maksimum) didapat dengan menjumlahkan hasil perkalian jumlah kolom dengan vektor eigen. Pada persamaan 5 dihitung nilai indeks konsistensi. Dimana Matrik berordo 3 (yakni terdiri dari 3 kriteria)

$$
\begin{aligned}
& \mathrm{CI}=(\mathbf{3 . 0 8 5 0 5 - 3}) /(3-1)=0.04252 \\
& \mathrm{CR}=0.58 / 0.04252=0.07332
\end{aligned}
$$

Pada persamaan 6 mencari nilai CR. Dimana untuk $\mathrm{n}=3, I R=0.58$ (Tabel Saaty). Karena $C R<0.100$ berarti prefensi responden adalah konsisten.

Dari Hasil perhitungan tabel diatas menunjukan bahwa kriteria yang paling penting bagi nasabah yang ingin mengajukan pengajuan kredit, yaitu: 


\section{JURNAL MEDIA INFORMATIKA BUDIDARMA}

Volume 5, Nomor 1, Januari 2021, Page 58-65

ISSN 2614-5278 (media cetak), ISSN 2548-8368 (media online)

Available Online at https://ejurnal.stmik-budidarma.ac.id/index.php/mib

DOI 10.30865/mib.v5i1.2466

a. Penghasilan dengan bobot 0.685 atau $68.5 \%$,

b. Kartu keluarga dengan nilai bobot 0.093 atau $9.3 \%$,

c. Domisili adalah 0.221 atau $22.1 \%$

\subsection{Penerapan SAW Dalam Perangkingan}

Metode SAW digunakan untuk perhitungan terakhir atau menentukan rangking yang paling sesuai untuk kelayakan pemberian kredit motor berdasarkan kriteria yaitu penghasilan, kartu kelurga dan domisili.

Adapun langkah langkah dalam penentukan perangkingan, yaitu:

1) Menentukan Kandidat simulasi Calon Nasabah, yaitu:

A1 : Yogi Danuarta

A2 : Suherman

A3 : Riko Setiadi

A4 : Diki Setiawan

A5 : Chandra Wijaya

Karena setiap nilai yang diberikan pada setiap alternatif di setiap kriteria merupakan nilai kecocokan (benefit nilai terbesar adalah terbaik, sedangkan cost nilai terkecil adalah yang terbaik), maka kriteria yang diberikan diasumsikan sebagai kriteria keuntungan (benefit) dan biaya (cost):

Tabel 4. Tabel kriteria dan atribut kriteria

\begin{tabular}{cccc}
\hline No & Nama Kriteria & Atribut & Nama Kriteria \\
\hline 1 & Penghasilan (Slip Gaji) & Cost & C1 \\
2 & Kartu Keluarga (KK) & Benefit & C2 \\
3 & Domisi (KTP) & Benefit & C3 \\
\hline
\end{tabular}

Berikut rating kecocokan antara alternatif dan kriteria yang dapat dilihat pada tabel 5.

Tabel 5. Tabel kriteria dan atribut kriteria

\begin{tabular}{ccccc}
\hline No & Alternatif & C1 & C2 & C3 \\
\hline 1 & A1 & 80 & 90 & 95 \\
2 & A2 & 95 & 95 & 95 \\
3 & A3 & 85 & 80 & 80 \\
4 & A4 & 80 & 75 & 85 \\
5 & A5 & 75 & 75 & 80 \\
\hline
\end{tabular}

Langkah berikutnya adalah melakukan normalisasi matrik untuk menghitung masing-masing kriteria, bedasarkan kriteria diasumsikan sebagai kriteria keuntungan (benefit) menggunakan persamaan 7 dan biaya (cost) menggunakan persamaan 8 .

Kriteria C1

$\mathrm{A}_{1,1}=\operatorname{Min}(80,95,85,80,75) / 80=75 / 80=0.938$

$\mathrm{A}_{2,1}=\operatorname{Min}(80,95,85,80,75) / 95=75 / 95=0.789$

$\mathrm{A}_{3,1}=\operatorname{Min}(80,95,85,80,75) / 85=75 / 85=0.882$

$\mathrm{A}_{4,1}=\operatorname{Min}(80,95,85,80,75) / 80=75 / 80=0.938$

$\mathrm{A}_{5,1}=\operatorname{Min}(80,95,85,80,75) / 75=75 / 75=1$

Kriteria C2

$A_{1,2}=90 / \operatorname{Max}(90,95,80,75,75)=90 / 95=0.947$

$\mathrm{A}_{2,2}=95 / \operatorname{Max}(90,95,80,75,75)=95 / 95=1$

$\mathrm{A}_{3,2}=80 / \operatorname{Max}(90,95,80,75,75)=80 / 95=0.847$

$\mathrm{A}_{4,2}=75 / \operatorname{Max}(90,95,80,75,75)=75 / 95=0.789$

$\mathrm{A}_{5,2}=75 / \operatorname{Max}(90,95,80,75,75)=75 / 95=0.789$

Kriteria C3

$\mathrm{A}_{1,3}=95 / \operatorname{Max}(95,95,80,85,80)=95 / 95=1$

$\mathrm{A}_{2,3}=95 / \operatorname{Max}(95,95,80,85,80)=95 / 95=1$

$\mathrm{A}_{3,3}=80 / \operatorname{Max}(95,95,80,85,80)=80 / 95=0.842$

$\mathrm{A}_{4,3}=85 / \operatorname{Max}(95,95,80,85,80)=85 / 95=0.895$

$\mathrm{A}_{5,3}=80 / \operatorname{Max}(95,95,80,85,80)=80 / 95=0.842$

Untuk nilai bobot preferensi vektor bobot (W) oleh pengambilan keputusan utuk masing-masing kriteria yang sudah ditentukan yaitu:

$\mathrm{W}=[0.685,0.093,0.221]$ yang diperoleh dari metode AHP sebelumnya. 
JURNAL MEDIA INFORMATIKA BUDIDARMA

Volume 5, Nomor 1, Januari 2021, Page 58-65

ISSN 2614-5278 (media cetak), ISSN 2548-8368 (media online)

Available Online at https://ejurnal.stmik-budidarma.ac.id/index.php/mib DOI 10.30865/mib.v5i1.2466

Langkah terakhir yaitu proses perankingan dengan menjumlahkan setiap alternatif dari matrik ternormalisasi (A) setiap baris di kalikan bobot $(\mathrm{W})$ dengan menggunakan persamaan 9 .
$\mathrm{V}_{1}=(0.685 \times 0.938)+(0.093 \times 0.947)+(0.221 \times 1)$
$=0.951$
$\mathrm{V}_{2}=(0.685 \times 0.789)+(0.093 \times 1)+(0.221 \times 1)$
$=0.855$
$\mathrm{V}_{3}=(0.685 \times 0.882)+(0.093 \times 0.847)+(0.221 \times 0.842)$
$=0.869$
$\mathrm{V}_{4}=(0.685 \times 0.938)+(0.093 \times 0.789)+(0.221 \times 0.895)$
$=0.913$
$\mathrm{V}_{5}=(0.685 \times 1)+(0.093 \times 0.789)+(0.221 \times 0.842)$
$=0.945$

Dari perhitngan di atas didapatkan hasil perankingan seperti pada tabel 6 berikut:

Tabel 6. Tabel Hasil Nilai

\begin{tabular}{cc}
\hline Alternatif & Hasil Nilai $(\mathbf{V i})$ \\
\hline A1 & 0.951 \\
A2 & 0.855 \\
A3 & 0.869 \\
A4 & 0.913 \\
A5 & 0.945
\end{tabular}

Dari hasil perhitungan dapat disimpulan bahwa alternatif $\mathrm{V}_{1}$ merupakan peringkat pertama karena memiliki nilai yang lebih besar dari nilai yang lain, $V_{1}$ merupakan nilai preferensi dari alternatif $A_{1}$, sehingga $A_{1}$ dalam kasus ini Yogi Danuarta yang menjadi alternatif terbaik atau Calon nasabah yang terpilih untuk mendapatkan kredit motor

\subsection{Implementasi Program}

Berikut merupakan tampilan dari implementasi program dari kelayakan pemberian kredit motor. Pada program terdapat beberapa form diantaranya Form Login, Form Daftar Nasabah, Form Daftar Kriteria, dan Form Penilaian.

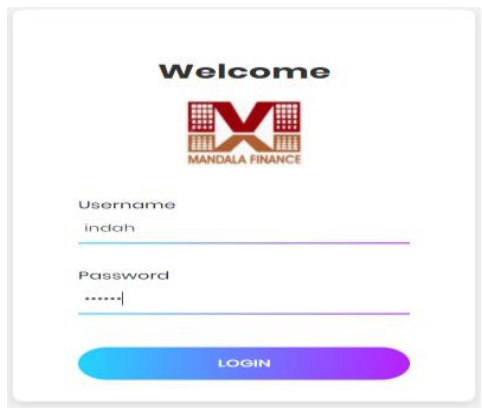

Gambar 3. Halaman Login
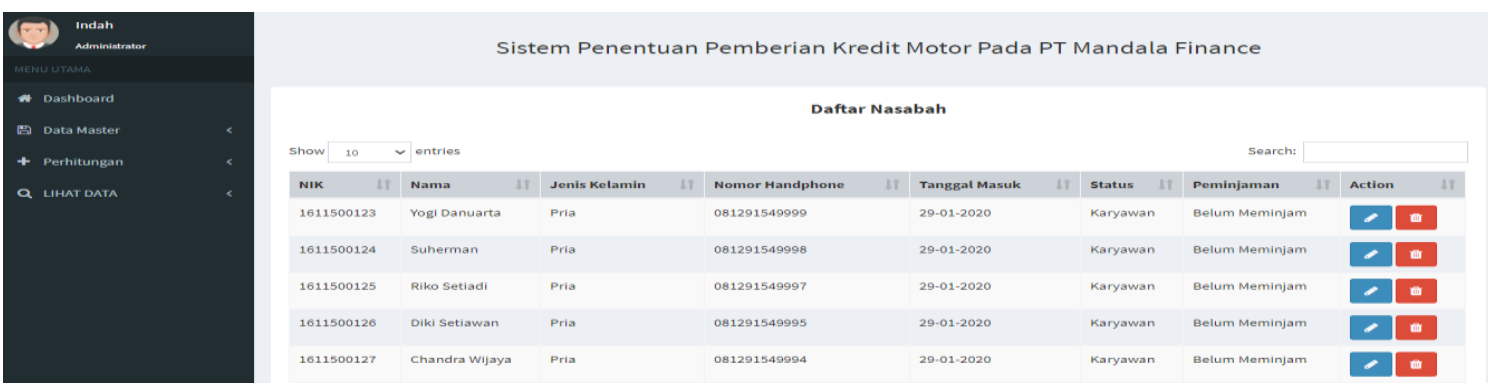

Gambar 4. Halaman Nasabah
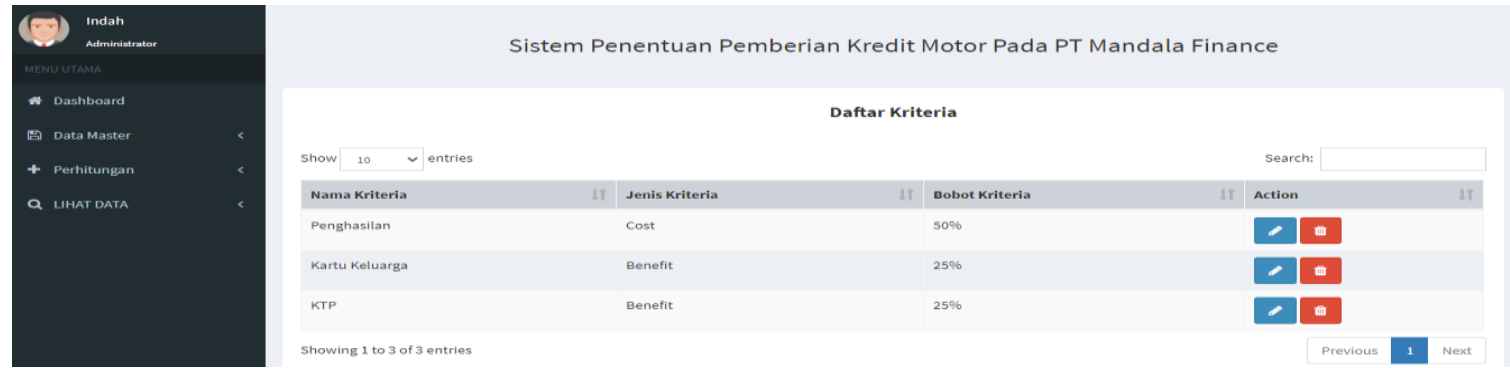

Gambar 5. Halaman Kriteria

Sarwindah, Copyright @2021, MIB, Page 64 Submitted: 04/09/2020; Accepted: 25/11/2020; Published: 22/01/2021 

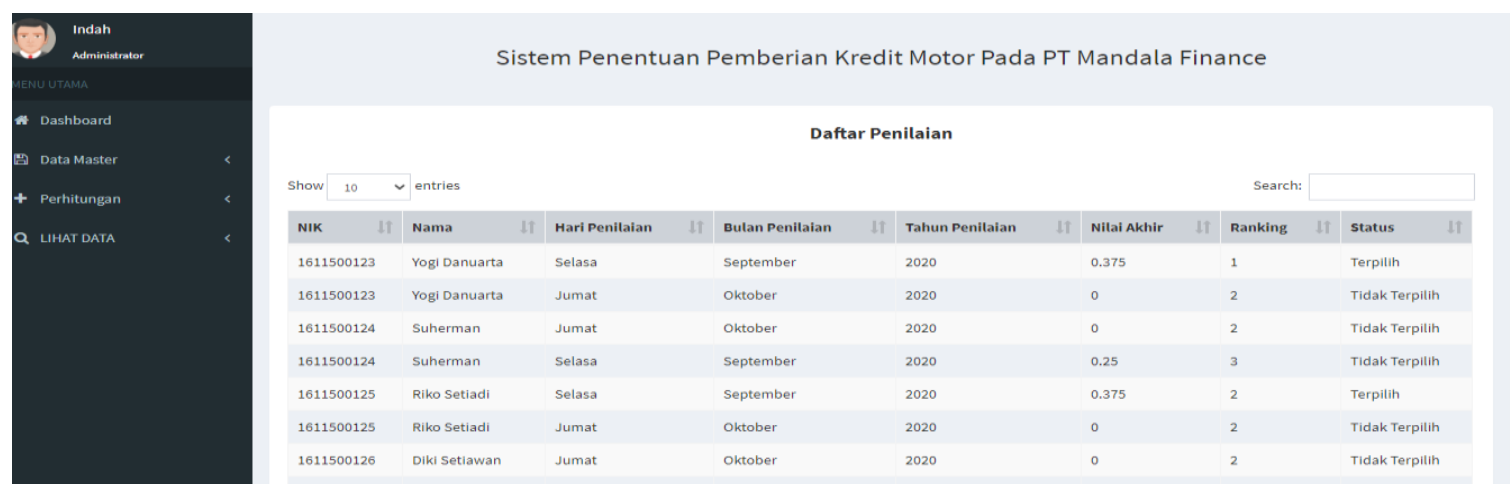

Gambar 6. Halaman Hasil Perangkingan dan Seleksi

\section{KESIMPULAN}

Berdasarkan hasil penelitian ini memiliki kesimpulan dimana hasilkan dari rata-rata nilai bobot relatif untuk tiap baris menunjukan bahwa kriteria yang paling penting bagi nasabah yang ingin mengajukan pengajuan kredit dengan metode AHP. Penghasilan dengan bobot 0,685 atau 68,5\%, kemudian disusul Kartu keluarga dengan nilai bobot 0,093 atau 9,3\%, dan Domisili adalah 0,221 atau $22.1 \%$. Hasil berdasarkan perengkingan menggunakan metode SAW Untuk Semua Kritera yang dinormalkan pembobotannya adalah didapatkan hasil perankingn $\mathrm{V}_{1}$ merupakan peringkat pertama karena memiliki nilai yang lebih besar dari nilai yang lain sebesar 0.951 dimana $V_{1}$ merupakan nilai preferensi dari alternatif $A_{1}$, sehingga $A_{1}$ dalam kasus ini Yogi Danuarta yang menjadi alternatif terbaik atau Calon nasabah yang terpilih untuk mendapatkan kredit motor.

\section{REFERENCES}

[1] Biasti handayani, "Perbandingan Metode AHP-SAWDengan FMCDM-SAWPada Pemberian Pinjaman Modal Usaha Pertanian", Jutisi, , Vol.3,No.3, 2014, AntokoWardani, 2013. Aplikasi Pemberian Bantuan Modal Usaha Pertanian menggunakan Metode SAW. Banjarbaru: STMIK Banjarbaru

[2] Oktaputra, Alif Wahyu And Noersasongko " Sistem Pendukung Keputusan Kelayakan Pemberian kredit motor menggunakan metode SAW pada perusahaan Leasing HD Finance",2014

[3] Sarwindah, marini (2020) "Penunjang Keputusan Dalam Kelayakan Pemberian Kredit Motor Pada PT.Mandala Multifinance ", JATISI,Vol.7,No.2, pp.299-309,2020.

[4] Amardyah Amborowati (2004). "Sistem Penunjang Keputusan Pemilihan Perumahan dengan Metode AHP menggunakan ExpertChoice",2004

[5] Sarwindah, "Sistem Penunjang Keputusan Pemilihan Perumahan Subsidi Berdasarkan KebutuhanKonsumen dengan metodeAHP," KNSI2018, pp. 668-673, 20018

[6] E. Sinaga and Erikson, Strategi Process Migrasi Proprietary Software Ke Open Source Software Di Perusahaan Dengan Pendekatan Analytical Hierarchy Process (AHP), Studi Kasus: SGU. Tanggerang, 2007.

[7] Sarwindah, "Kajian Pemilihan Software Desain Grafis Untuk Pembelajaran Dengan Metode AHP Pada SMK Muhamadiyah 9," SEMNASTEKNOMEDIA, 2013.

[8] Tanto, "Perancangan Sistem Pendukung Keputusan Pemberian Kredit Pemilikan Rumah (Kpr) Dengan Metode Simple Additive Weighting," 2014

[9] Adianto and T. dkk Reza, . "Sistem Pendukung Keputusan (SPK) PemilihanRumah Tinggal di Perumahan Menggunakan Metode Simple Additive Weighting (SAW) (STUDI KASUS : KOTA SAMARINDA)," Pros. Semin. Ilmu Komput. dan Teknol. Inf., vol. Vol. 2, No, pp. 197-201, 2017.

[10] Butar-Butar and Oktovantua, . "Sistem Pendukung Keputusan Rekomendasi Penerima Bantuan Siswa Miskin (BSM) Dengan Metode Simple AdditiveWeighting (SAW) (Studi Kasus : SMP N2 Tarabintang).," Inform. Budi Darma, vol. IX Nomor:, pp. 162-165, 2016.

[11] Bunafit, N., 2013, Dasar Pemrograman Web PHP - MySQL Dengan Dreamweaver, GavaMedia, Yogyakarta

[12] A. Amborowati, "Sistem Penunjang Keputusan Pemilihan Perumahan dengan Metode AHP menggunakan ExpertChoice," AMIKOM, 2004.

[13] Sotir, Sotirov, Andrey, and Nenov, "Tutorials Expert Choice," Comput. Sci. J., vol. Vol.4 No.1, 2006.

[14] Sarwindah, "Sistem Penunjang Keputusan Pemilihan Perumahan Subsidi Berdasarkan KebutuhanKonsumen dengan metodeAHP," KNSI2018, pp. 668-673, 20018.

[15] Haeran Ellin and Ramdaril, . "Sistem Pendukung Keputusan Pendistribusian Zakat pada BAZNAS Kota Pekanbaru Menggunakan Fuzzy Multiple Attribute Decission Making (FMADM) dan Simple Additive Weighting (SAW), J. Ilm. Tek. Inform., vol. vol.10 No., pp. 159-168, 2017.

[16] Lipursari and Anastasia,. "Peran Informasi Manajemen (SIM) DalamPengambilan Keputusan," J. STIE SEMARANG, vol. Vol. 5, No, pp. 26-37, 2013. 